Libraries in the Ancient World 



\title{
Libraries in the
}

Ancient World

\section{LIONEL CASSON}

\author{
$\mathrm{NB}$ \\ YALE NOTA BENE \\ Yale University Press/New Haven and London
}


First published as a Yale Nota Bene book in 2002.

Hardcover edition first published by Yale University Press in 2001.

Copyright $\odot 2001$ by Yale University.

All rights reserved. This book may not be reproduced, in whole or in part, including illustrations, in any form (beyond that copying permitted by Sections 107 and 108 of the U.S. Copyright Law and except by reviewers for the public press), without written permission from the publishers.

For information about this and other Yale University Press publications, please contact:

U.S. office sales.press@yale.edu

Europe office sales@yaleup.co.uk

Printed in the United States of America

The Library of Congress has cataloged the hardcover edition as follows:

Casson, Lionel, 1914-

Libraries in the ancient world / Lionel Casson.

p. $\mathrm{cm}$.

Includes bibliographical references and index.

ISBN 0-300-08809-4 (alk. paper)

1. Libraries-History-To 400. I. Title.

Z722. C37 2001

027'.09-dc21 00-011668

ISBN 0-300-0972 1-2 (pbk.)

A catalogue record for this book is available from the British Library. 
To Judy 
